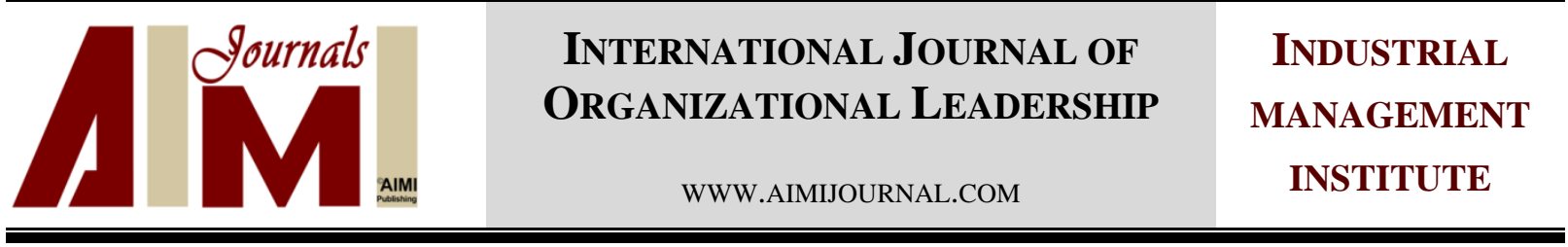

\title{
Intention to family Takaful adoption: A review theory and empirical work
}

\author{
Shahab Aziz ${ }^{1 *}$, Maizaitulaidawati Md Husin ${ }^{2}$, Nazimah Hussin ${ }^{3}$ \\ ${ }^{1} \mathrm{PhD}$ Scholar, International Business School, University Technology Malaysia (UTM) \\ ${ }^{2,3}$ Senior Lecturer, International Business School, Universiti Teknologi Malaysia (UTM)
}

\begin{abstract}
Keywords:

Takaful, Adoption, Attitude, Subjective Norm, Perceived Behavioural Control, Intention

Received

09 May 2016

Received in revised form 01 August 2016

Accepted

18 August 2016

Correspondence:

shahabaziz7@hotmail.com

The aim of this paper is to review intention behaviour theories to identify relevant theoretical model for the intentions of adoption of family Takaful. In this paper different intention behaviour theories including Theory of Reasoned Action (TRA), Theory of Planned Behaviour (TPB), Attitude-Social Influence-Efficacy Model (ASE), Innovation Diffusion Theory (IDT), and Decomposed Theory of Planned Behaviour (DTPB) have been discussed. Family Takaful companies face stiff competition from conventional life insurance companies and family Takaful companies have low market share around the globe as compared to conventional life insurance. This problem needs to be addressed and researched on and the question of what may drive individuals to adopt family Takaful needs to be addressed and explored. The significance of this paper stems from the fact that marketing strategy of any organization has a pivotal role in success of any brand. Family Takaful companies need to know and understand the factors which influence individual's intention to purchase family Takaful. In this paper most appropriate theoretical model is proposed after discussing the relevant intention behaviour theories in order to develop understanding of factors relevant to adoption of family Takaful. This understanding will lead to devise effective marketing strategies, competitive advantage, and greater market share for family Takaful companies.
\end{abstract}

(C)AIMI Journals

In insurance two parties enter into a contract whereby risk of one person is transferred to another against payment of a certain amount called insurance premium. An insurance company is the one who sells insurance policies. Insurance premium is charged by the insurance companies keeping in view the risks involved. Higher insurance premium will be charged for insurance involving high risk and lower if less risk is involved. Insurance companies manage risk by attracting large numbers of policy holders. 
Islam as a religion defines principles on almost every aspects of human life. Islamic economic system and ways of doing business in Islamic way is not an exception. In modern economic systems interest plays a pivotal role in development of an economy. Islamic economic, on the other hand, rejects the idea of interest and encourages trade and partnership oriented business activities. In Islamic economic system interest (Riba), gambling (Maisir), and uncertainty (Gharar) are considered prohibited (Amin, Abdul Rahman, Stephen, \& Hwa, 2011).

Conventional insurance is in contradiction to Islamic Shariah due to presence of Gharar, Maisir, and Riba. There is Ghararin insurance contract for both situations if loss occurs or not. If there is no loss, policy holder receives nothing and in case of loss, uncertainty remains to the extent of sharing of loss amount by insurance company. Maisir exists in insurance as policy holder receives huge sum against a small premium if loss or event occurs and losses whole premium in case event or loss do not occur. Conventional insurance invests premium in Riba based modes which is prohibited in Islamic Shariah.

The concept of modern day Takaful has emerged along with Islamic banking in 1979. Takaful is an Arabic term derived from the word kafalah meaning guarantee, bail, and warrant (Ali, 2006). Ahmed, Juliana, Mohd, \& Wan Norhayate (2012) defines Takaful as joint guarantee. Accounting Auditing and Governance Standards for Islamic Financial Institutions (AAOIFI) defines Islamic Insurance as an agreement between persons who are exposed to risks to protect themselves against harm arising from risk by paying contributions on the basis of a commitment to donate. Moreover, Islamic Financial Services Board (IFSB) and International Association of Insurance Supervisors (IAIS) described Takaful as the Islamic counterpart of conventional insurance which can exist in either life or family and general forms.

Takaful has two types one is family Takaful and other is general Takaful which are Shariah compliant substitute of life and general insurance. General Takaful covers losses such as fire, burglary, and flood. Family Takaful covers risks associated with human life, namely death, illness, and disability and also cater for investment needs. According to Hofstede (1995) the purpose of life insurance is to get protection from any financial loss occurring due to human life. There are three reasons for adoption of family Takaful; first, contribution of Takaful premium for a certain period of time;second, to earn Shariah complaint returns on investment; andthird, to get other coverage benefits in the form of death, disability or illness (Ahmad et al., 2012; Hendon, Zuriah,\& Sharifah, 2009).

Like Islamic banking, Takaful has also grown in the world and has established in Muslims and nonMuslim countries. Takaful plays a vital role in modern day risk management. The concept of Islamic insurance i.e. Takaful is Shariah compliant replacement of conventional insurance. Takaful companies facechallenge of stiff competition from conventional insurance companies. Therefore, family Takaful companies needs to devise effective marketing strategies in order to grow and increase their market share. For developing effective marketing strategy, it is vital for Takaful companies to explore and find out what actually drives individuals' intention to participate in family Takaful. This study is based on intention behaviour theories to develop a model to study consumer intentions to adoption of family Takaful.

\section{Intention Behaviour Theories}

In literature, there are a number of theories used to study intention behaviour relationship. These theories comprise of Theory of Reasoned Action (TRA), Theory of Planned Behaviour (TPB), AttitudeSocial Influence-Efficacy Model (ASE), Innovation Diffusion Theory (IDT), and Decomposed Theory of Planned Behaviour (DTPB). These theories are discussed in the following section. 


\section{Theory of Reasoned Action (TRA)}

Ajzen and Fishbein (1980) have presented Theory of Reasoned Action (TRA) and there are three constructs that constitute this theory, namely behavioural intention and attitude and subjective norms (Figure 1). Theory of Reasoned Action is concerned with individual's behaviour and motivation to do a certain action. According to Ajzen and Fishbein (1980), TRA helps to explain and predict human behaviour. This theory is based on two assumptions; first assumption states thatmost of the human actions are under volitional control and second assumption is that human actions are determined by intentions.

Venkatesh, Morris, Davis, \& Davis (2003) states that TRA is the basic theory to elucidate human behavior. This theory states that it is the intention which leads to a certain behaviour and this intention is called behavioural intention. According to TRA these behavioural intentions are shaped by attitudes and subjective norms. Attitude is the opinion about behaviour either positive or negative whereas subjective norm is the social pressure to perform certain behaviour or not. This theory has largely been applied in psychology in order to explain human behaviours.

TRA has been used in many disciplines to explain human behaviour (Aminet al., 2011; Lada, Tanakinjal, \&Amin, 2009; Ramayah, Lee,\& Osman, 2010). Study conducted by Lada et al. (2009) showed that TRA is valid for choosing halal products. Ramayah et al.(2010) has conducted their study regarding intention to purchase green products in developing countries. Another study conducted by Summers, Belleau, \& Xu (2006) proved that TRA model is valid in predicting intention to purchase luxury products. It isproved that intention to engage in diminishing partnership is determined by religious and social influence. TRA has also been used in measuring intention in the context of financial services (Amin et al., 2011;Amin \& Chong, 2011; Fauziah, Ramayah, \& Dzuljastri, 2008; Olaniyi\& Echchabi, 2012; Omar, 2007; Omar \& Frimpong, 2007).

In context of individuals' intention to adopt family Takaful TRA can also be applied in order to take into account the factors which determine adoption to purchase intentions. Attitudes regarding adoption of family Takaful are shaped by individual's belief that they will get protection of risk if they purchase Takaful policy. Subjective norms also have role in shaping individual's attitude to make purchase decision. Individual's choices are affected by what friends and family wants them to do or do not. Figure 1 shows the Theory of Reasoned Action (TRA) (Fishbein \& Ajzen, 1975).

There are certain limitations of this theory and on the basis of these limitations TRA has been criticized. According to Aiken (2002), the model is questioned that it does not explain that past behaviour is the best predictor of future behaviour. Some of the criticism on TRA is that under some situations its explanatory power will decrease if behavior is influenced by willpower, skills, and opportunities available; if before performing an act intentions changes; and if intentions are not measured accurately in term of action or context (Ajzen 1985; Sheppard, Hartwick, \& Warshaw, 1988). TRA does not incorporate perceived behavioural control. Ajzen's (1988) presented Theory of Planned Behavior to address some of the shortcomings of TRA. 


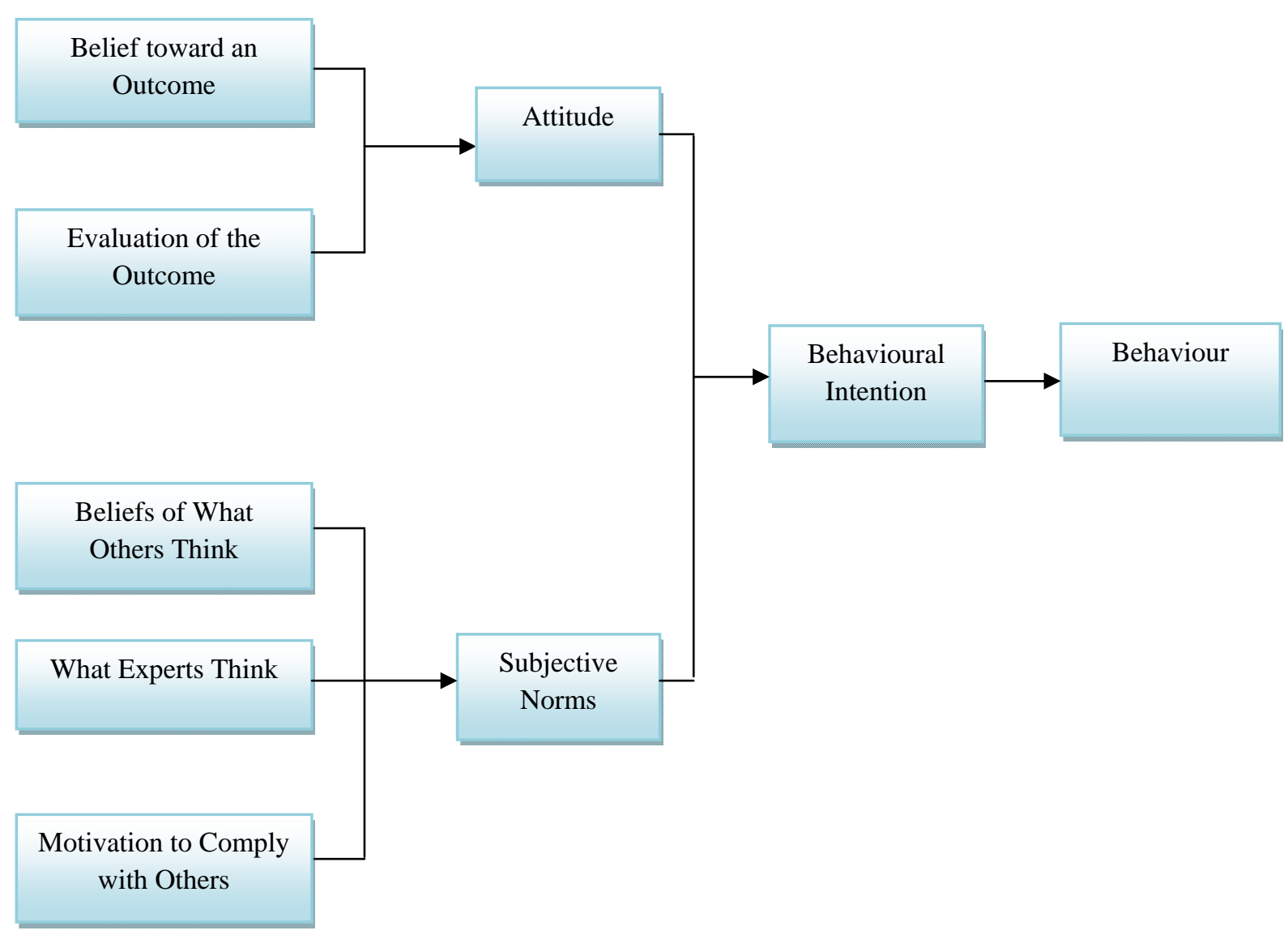

Figure 1. Theory of Reasoned Action (TRA)

\section{Theory of Planned Behaviour (TPB)}

Theory of Planned Behaviour (TPB) is an extension of Theory of Reasoned Action (TRA). (Ajzen \& Fishbein, 1980; Fishbein \& Ajzen, 1975). TPB provides one of the most dominant conceptual framework in order to study human behaviour (Ajzen, 2001). TRA deals with behaviors which are under volitional control (Ajzen \& Fishbein, 1980). TPB extends and incorporate behaviors affected by non-voluntary variables (Ajzen, 1985). According to Ajzen (1991), TPB incorporates attitudes, subjective norms, and perceived behavioural control to predict intentions with higher accuracy (Figure 2).

Theory of Planned Behavior comprises of three components which determine Behavioural Intentions (BI), Attitude (Att), Subjective Norms (SN), and Perceived Behavioral Control (PBC). Attitude is determined by behavioural beliefs, subjective norms are explained by normative beliefs, and control belief determines perceived behavioural control. Attitude refers to the measurement of evaluation of a performance of certain behaviour. Subjective norms are the external factors referring to others thoughts about action or behvaiour. On the other hand, perceived behavioural control is intended to measure to what extent an individual believes about his ability to perform behaviour. Perceived behavioural control is the additional variable included in the model of TPB. Behaviour of the people is dependent upon the level of control they possess. The chances of certain behaviour will be low if the control element is low in spite of favorable attitude and subjective norms. The notion was proved by 
Bundara, Adam, Hardly, and Howells (1980) that behaviour is determined by confidence of an individual to have control of performing a behaviour.

In context of individual's intention to adopt family Takaful, TPB can also be applied. Attitude states that to what extent individual has belief in adopting family Takaful for risk protection. Second construct of the theory i.e. subjective normexpresses that how much influence family and friends have in shaping individual's adoption of family Takaful. Perceived behavioural control is the self-belief and having required resources to participate in family Takaful. Other studies conducted by many researchers including Al-Jabari, Othman, and Mat (2012), Armitage and Conner (2001), Armitage (2005), Bhattacherjee (2000), Chun and Chun (2010), Fen and Sabaruddin (2008), Fukukawa (2002), Leng, Lada, Muhammad, Ibrahim, and Amboala (2011), and Syed and Nazura (2011) also confirmed that perceived behavioural control is a significant determinant of intention to engage in certain behaviour. Figure 2 presents the Theory of planned behaviour (TPB) (Ajzen 1988).

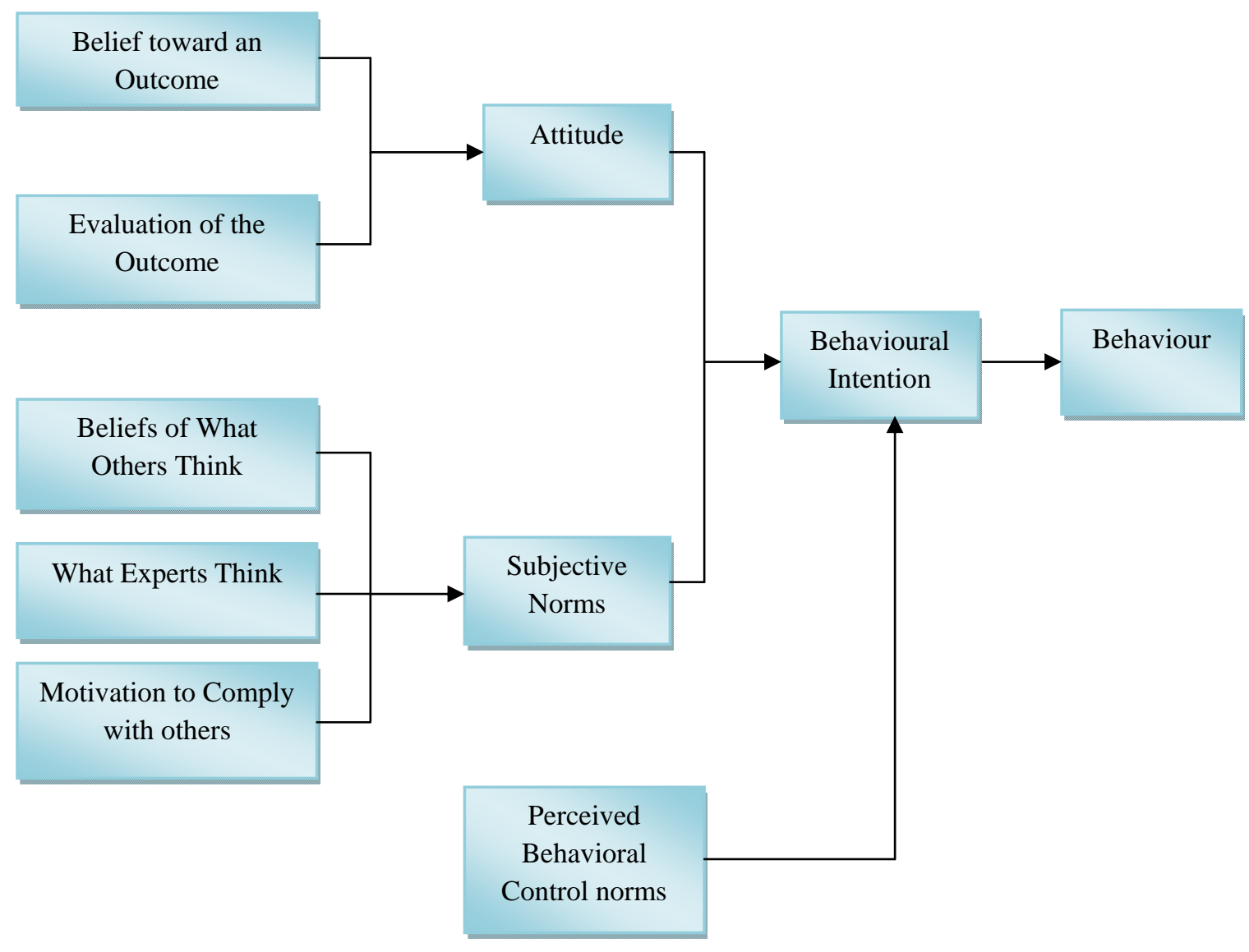

Figure 2.Theory of planned behaviour (TPB)

TBP has been applied to financial services industry as well (Alam, Janor, Zanariah, Wel, \& Ahsan, 2012; Hasnah, Ishak, \& Shaikh, 2011; Raedah, Noormala, \& Marziana, 2011; Siang and Weng, 2011). Hasnah et al., (2011) carried out study regarding immoral behvaiour of insurance agents. The results of the study showed that attitude have mediating role to determine intentions and sales target, role ambiguity, and supervisory influence. Siang and Weng (2011) used TPB and found that attitude, 
subjective norms, and perceived behavior control construct have significant influence in determining intention to purchase Islamic banking products by non-Muslims living in Malaysia.

However, there are certain limitation and criticism on TPB. The theory is criticized as it does notincorporate emotions (Conner \& Armitage, 1998; Gibbons, Gerrard, Ouelette, \& Burzette, 1998; Van Der Pligt, Zeelenberg, van Dijk, de Vries, \& Richard, 1998). Ajzen (2002) has responded to this criticism that emotions are accounted for in attitude and beliefs which are determinants of intentions to behaviour. In spite of limitations, the theory has been known and used for determining intentions to behvaiour in many disciplines.

\section{ASE Model (ASE)}

ASE model is a combination of Fishben and Ajzen's (1975) Theory of Reasoned Action and Bandura's (1986) Social Cognitive Theory. This theory describes to predict volitional behaviour. This model is comparable with Theory of Planned Behaviour (Ajzen \& Madden, 1986). According to this theory, there are three factors that influence intention and behavior, namely attitude, social influence, and selfefficacy (Figure 3). Behaviour is determined by intentions and intentions are shaped by attitude, social influence, and self-efficacy. Figure 3 exhibits ASE model, Adapted from Vries, Dijkstra, and Kuhlman (1988).

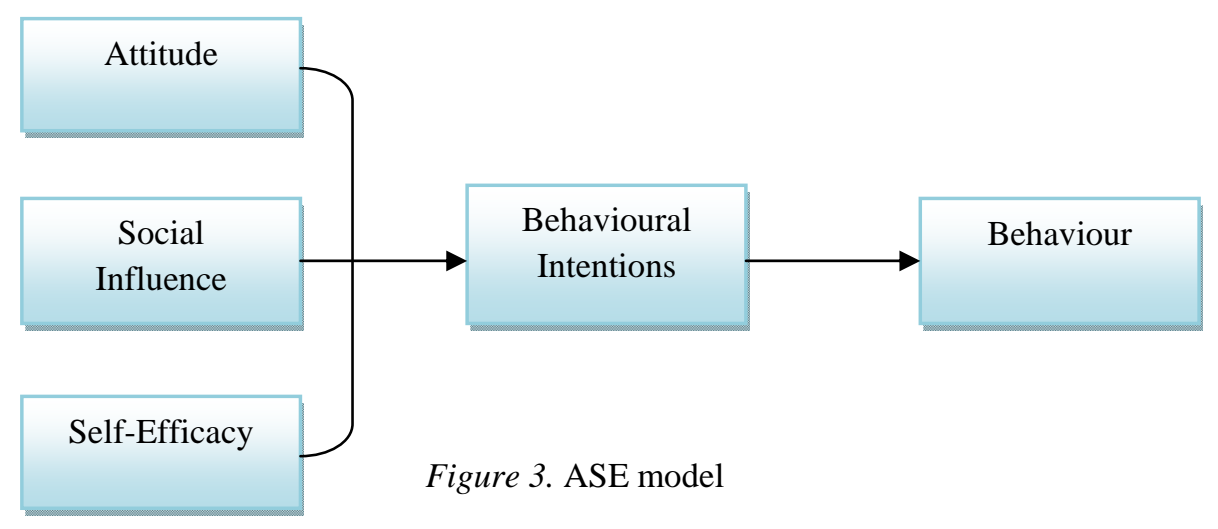

Attitude is the expected result of what an individual perceives while performing a certain behavioursuch as adoption of family Takaful to get the benefits as savings and risk protection. Social influence is the social pressure exerted to participate or not. There are more chances to act or behave in a certain way if it is socially acceptable. In the present case, adopting family Takaful will be easier if there is positive social response of adopting it. Self-efficacy is one's belief of his abilities or resources to perform a certain act, for example, having enough resources to adopt family Takaful.ASE-model has been widely adapted in various research areas (Amooti Kaguna \& Nuwaha, 2000; Li, Yu, Hu, \& Huang, 2003; Van Es, Kaptein, Bezemer, Nagelkerke, Colland, \& Bouter, 2002; Vries \& Mudde, 1998).

\section{Innovation Diffusion Theory (IDT)}

Innovation of Diffusion Model was presented by Rogers (1983) which explains how and why technology spread across different cultures. According to Rogers, innovation is an idea, practice, or object that is perceived as new by an individual or other unit of adoption. On the other hand, diffusion is process that an innovation needs to spread through communication channel over time among people in the community. This process is achieved through various communication channels. The model originally consists of five dimensions, namely compatibility, relative advantage, complexity, trialability, 
and observability. Researchers have adapted these dimensions and some context original dimensions are replaced with more relevant phenomenon (Figure 4).

In case of family Takaful adoption uncertainty can have negative impact as it will stop individuals to participate. Relative advantage will have positive impact on adoption. Compatibility is an important aspect as family Takaful needs to be in line with customer's belief of its being Islamic and having Islamic religious practices. Positive social influences and awareness will have positive impact and will help individuals to adopt family Takaful.

Figure 4 shows the diffusion of innovation model (Rammal, \& Zurbruegg, 2007; Thambiah, Eze, Tan, Nathan, \& Lai, 2010).

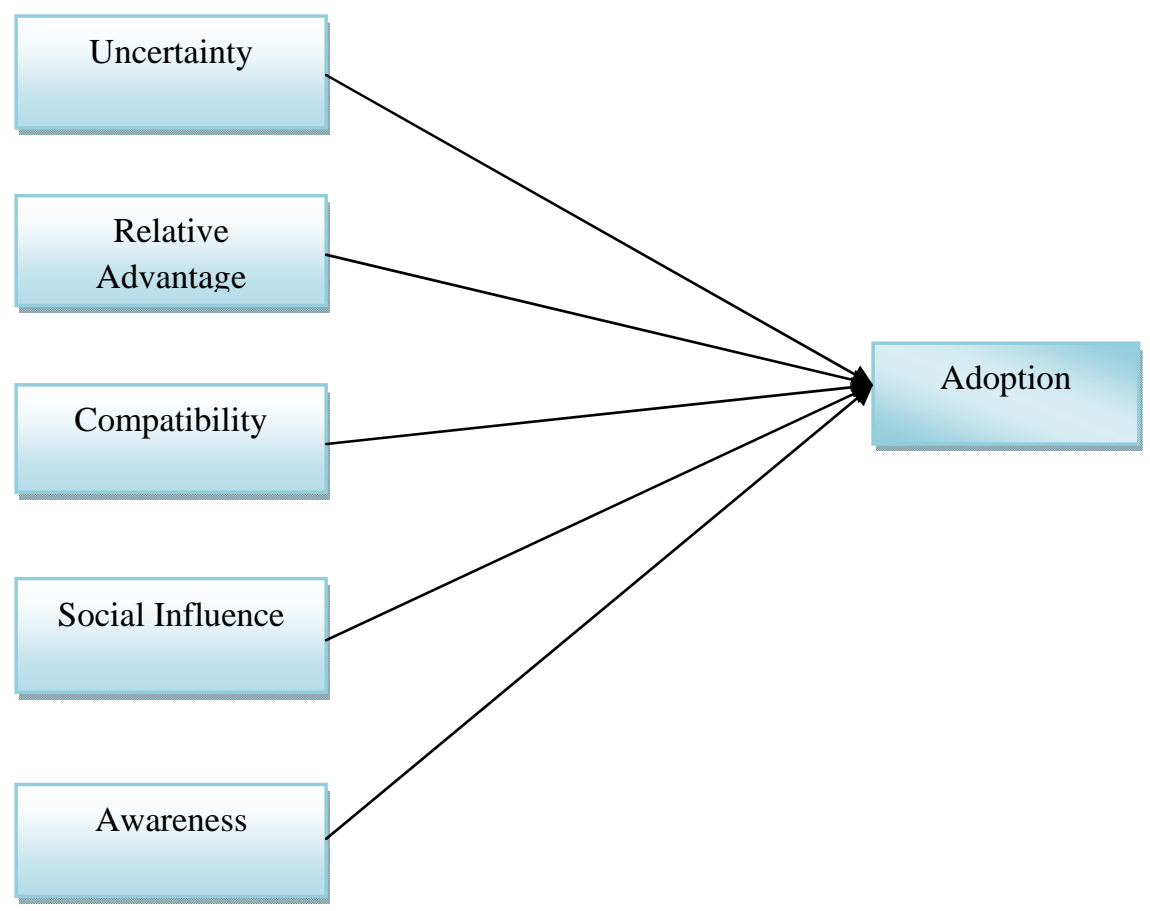

Figure 4. Diffusion of innovation model

There are a number of studies conducted in Islamic finance context using this theory. Thambiah et al. (2010) found that uncertainty and awareness are the important determinants of Islamic banking and financial service adoption. Few of other studies have found similar findings such as Abdullah and Abdul Rahman (2007) and Rammal and Zurbruegg (2007). Study conducted by Olaniyi and Echchabi (2012) in context of Islamic insurance asserted that social influence is also one of the determinants in adoption of Islamicinsurance.

\section{Decomposed Theory of Planned Behaviour (DTPB)}

Taylor and Todd (1995) presented Decomposed Theory of Planned Behaviour (DTPB) which describes three dimensions of human behavior including attitude, subjective norms, and perceived behavioural control. This theory is a combination of Theory of Planned Behvaiour and Technology Acceptance Model. In original theory attitude, subjective norms and perceived behavioural control are further supported by multidimensional constructs to study behavioural intentions towards information technology (Figure 5). Figure 5 presents the Decomposed Theory of Planned Behaviour (Taylor \& Todd, 1995). 


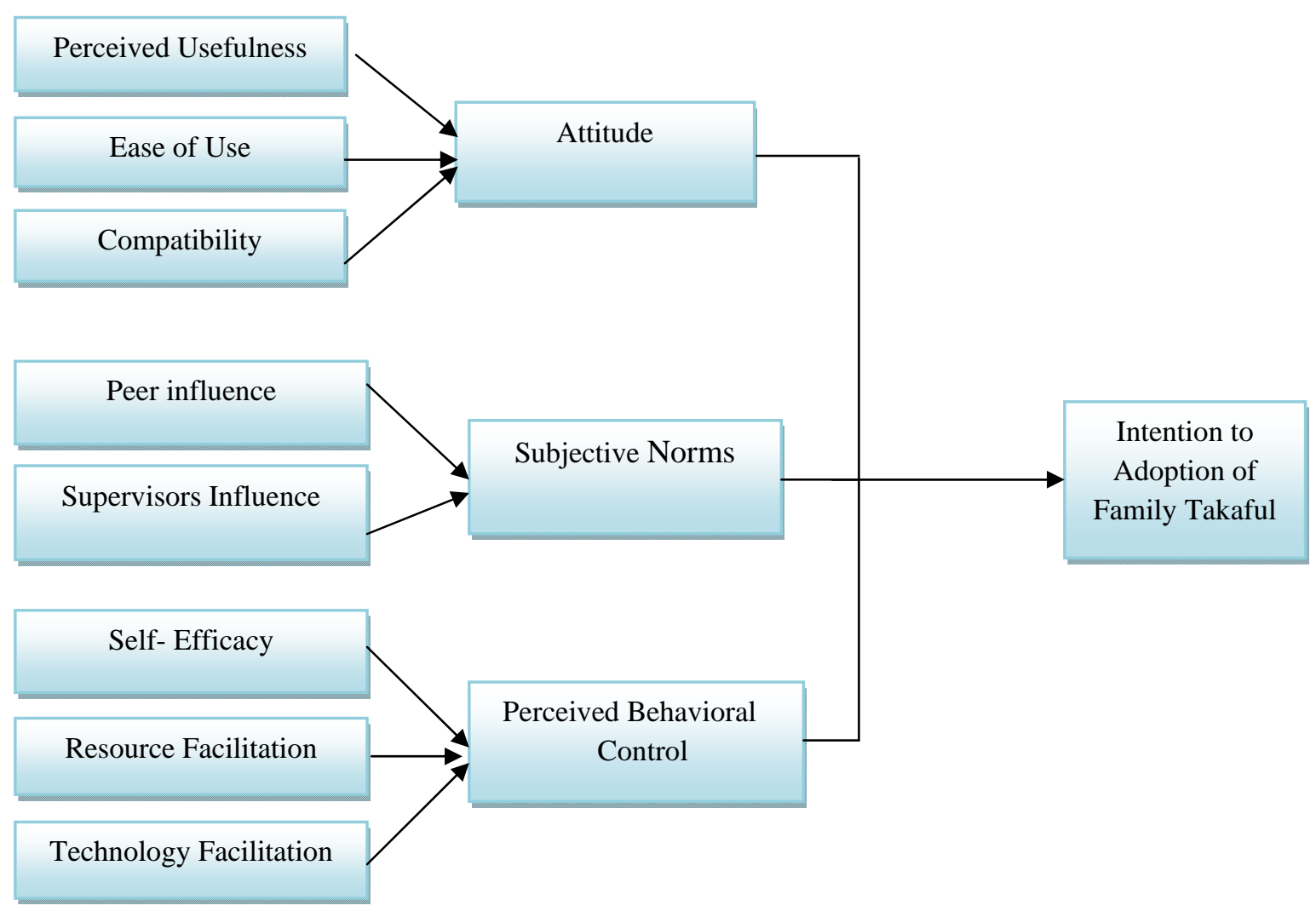

Figure 5. Decomposed Theory of Planned Behaviour

Research has confirmed that Decomposed Theory of Planned Behaviour incorporates innovation literature along with normative and control beliefs and measures intention to adoption more accurately than TPB (Jaruwachirathanakul \& Fink, 2005).

In DTPB (Taylor \& Todd, 1995) attitude is determined by relative advantage complexity and compatibility which is mainly influenced by Diffusion Theory of Rogers (1995). While explaining subjective norms the original model of DTPB has used peer influence and superior influence. In an organization, there are three main players including peers, superiors, and subordinates. Peers and superiors have a strong role in shaping individual's behaviour in an organization. Taylor and Todd (1995) have decomposed subjective norms into peer influence and superior influence regarding the use of IT in an organization. The rational of decomposing peer influence and superior influence is due to different views regarding use of IT in an organization. For example, in an organization one's peer might be against the use of particular system due to cost involved and changes require implementing it. At the same time, one's superior might be in favor of the new system due to the benefits and returns expected to be achieved. Due to different expectations normative beliefs have been decomposed into these referent groups.

In original model of DTPB, three latent variables, namely self-efficacy, resource facilitation, and technology facilitation were used to determine perceived behavioural control. This decomposition of control beliefs has been taken directly from Ajzen' $(1985,1991)$ discussion. Self-efficacy is related to internal notion of an individual's perceived ability whereas resource facilitation is an external phenomenon. In original model self-efficacy is the perceived ability of using IT. The higher will be intention to use IT if self-efficacy will be higher. With respect to IT usage the original construct of 
control belief was decomposed in resource facilitation and technology facilitation where resources such as time and money and technology facilitation is technical ability to use IT.

DTPB has shown better explanatory power in explaining the behavioural intentions in comparison to TPB and is proven robust model in explaining behaviour regarding Information systems (Beiginia, Besheli, Soluklu, \& Ahmadi, 2011; Bhattacherjee, 2000). DTPB have been used in the study of financial services because theory can be modified to incorporate the relevant variables (Taylor \& Todd. 1995).

\section{The relevancy of intention behaviour theories to family Takaful adoption}

Family Takaful companies face challenge of stiff competition from conventional life insurance companies in most of Muslim population countries. There exists huge untapped family Takaful market in these countries. Therefore, family Takaful companies need to devise effective marketing strategies to grow and increase their market share. For developing effective marketing strategy, it is vital for Takaful companies to explore and find out what actually drives individual's intention to participate in family Takaful.

Intention behaviour theories have been adopted by many disciplines in order to find out factors contributing to adoption of various products. These theories have potential to help in identifying variables relevant to adoption of family Takaful. In this paper different intention behaviour theories are discussed which include TRA, TBP, ASE, IDT, and DTPB. These theories are relevant to each because some are extension or combination of others; therefore, some of the constructs overlap in these theories.

This paper proposed that DTPB can be used as a starting point to build a theoretical foundation to find out factors influencing intention to adoption of family Takaful. DTPB was presented by Taylor and Todd (1995) which is a combination of TPB and TAM. In DTPB original construct of TBP including attitude, subjective norms, and perceived behavioural control were further decomposed. DTPB has been considered better in explaining intentions to purchase due to few reasons. Firstly, DTPB incorporates several antecedents to explain relationship better. Second, decomposing beliefs allow flexibility and can be applied in various settings. There has been very little application of this theory in family Takaful research. Study based on DTPB will not only help to enrich existing literature on family Takaful by incorporating different variables but also will help in improving the understanding of intentions to adoption of family Takaful. This can lead to devising effective marketing strategy and improved market share.

\section{Conclusion}

Different intention behaviour theories have been discussed starting from Theory of Reasoned Action (TRA) followed by Theory of Planned Behavior (TPB) with the addition of another variable, namely perceived behavior control to account for behaviors which are not under volitional control. ASE model is discussed which is the combination of Theory of Reasoned Action and Social Cognitive Theory. Innovation Diffusion theory (IDT) has been discussed which is based on the adoption of innovations. Lastly, Decomposed Theory of Planned Behavior (DTPB) is discussed which is a combination of Technology Acceptance Model and Theory of Planned Behvaiour. DTPB was presented by Taylor and Todd (1995). In DTPB original construct of TBPsuch as attitude, subjective norms, and perceived behavioural control were further decomposed. According to Jaruwachirathanakul and Fink (2005) DTPB incorporates innovation literature along with subjective norms and behavioural control phenomenon and is better in explaining intention to adoption in comparison to traditional TBP. DTPB as proposed by Taylor and Todd (1995) has several advantages in comparison to TPB. Firstly, DTPB incorporates several antecedents to intentions which make relationships very clear. Secondly, decomposed belief structures can be applied in variety of settings helping to overcome some of the 
disadvantages of traditional models. Finally incorporating specific beliefs help to identify specific factors which are relevant to intentions in adoption. According to Taylor and Todd (1995), some of the advantages of DTPB are similar to TAM, however,the difference is that DTPB is more complex and incorporates more variables. On the basis of above advantages, DTPB is considered as superior in determining human intentions to adopt certain behaviour. On the basis of DTPB, a theoretical framework can be developed to determine factors that contribute to consumers' intentions to adoption of family Takaful. The DTPB model was initially presented for information technology usage; however, it is used in financial service industry with some modifications. There are numerous studies conducted regarding consumer behaviour of Islamic financial products on the basis of theories of planned behaviour (Alam et al., 2012; Echchabi \&Aziz, 2012; Rutherford \& DeVaney, 2009; Nurul, Yosi, Purnama, 2012). There has been limited application of this theory in family Takaful. This study will help to enrich existing Takaful literature by using DTPB and incorporating antecedents relevant to family Takaful which have not been incorporated before in explaining intention to adoption of family Takaful.

\section{References}

Abdullah, R. F. S., \& Abdul Rahman, A. (2007). Factors influencing knowledge of Islamic banking services: The case of Malaysian bank managers. Review of Islamic Economics, 11(2), 31-54.

Ahmad, S. Y., Juliana, A., Mohd. R. H., \& Wan Norhayate, W. D. (2012). Determinants of family takaful (Islamic life insurance) demand: A conceptual framework for a Malaysian study. International Journal of Business \& Management, 7(6), $115-127$.

Aiken, L. (2002). Attitude and related psychosocial constructs.Thousand Oaks, CA: Sage.

Ajzen, I. (1985). From intentions to actions: A theory of planned behavior. In J. Kuhl \& J.Bechmann (Eds), Action control: From cognition to behavior (pp. 11-39). Heidelberg, Germany: Springer.

Ajzen, I. (1988). Attitudes, personality, and behavior. Chicago, IL: Dorsey Press.

Ajzen, I. (1991). The theory of planned behavior. Organisational Behavior \& Human Decision Processes, 50, $179-211$.

Ajzen, I. (2001). Attitudes. Annual Review of Psychology, 52, 27-58.

Ajzen, I. (2002). Perceived behavioral control, self-efficacy, locus of control, and the theory of planned behavior. Journal of Applied Social Psychology, 32(4), 665-683.

Ajzen, I., \& Fishbein, M. (1980). Understanding attitudes and predicting social behaviour. Englewood Cliffs, NJ: PrenticeHall.

Ajzen, I., \& Madden, T. J. (1986). Prediction of goal-directed behavior: Attitudes, intentions, and perceived behavioral control. Journal of ExperimentalSocial Psychology, 22, 453-474.

Alam, S. S., Janor, H., Zanariah, Wel, C. A., \& Ahsan, M. N. (2012). Is religiosity an important factor in influencing the intention to undertake Islamic home financing in Klang Valley? World Applied Sciences Journal, 19(7), 1030-1041.

Ali, R. (2006). Islamic finance: A practical guide. London, U. K.: Globe Business Publishing.

Al-Jabari, M. A., Othman, S. N., \& Mat, N. K. N. (2012). Actual online shopping behavior among Jordanian customers. American Journal of Economics, 2(4), 125-129.

Amin, H., Abdul Rahman, A. R., Sondoh, S. L., Chooi Hwa, A. M. (2011). Determinants of customers' intention to use Islamic personal financing: The case of Malaysian Islamic banks. Journal of Islamic Accounting \& Business Research, 2242.

Amin, H., \& Chong, R. (2011). Is the theory of reasoned action valid for Ar-Rahnu? An empirical investigation. Australian Journal of Basic \& Applied Sciences, 5(10), 716-726.

Amin, H., Abdul Rahman, A. R., Stephen, L. S. J., \& Hwa, A. M. (2011). Determinants of customers’ intention to use Islamic personal financing: The case of Malaysian Islamic banks. Journal of Islamic Accounting \& Business Research, 2(1), $22-42$.

Amooti-Kaguna, B. A., \& Nuwaha, F. (2000). Factors influencing choice of delivery sites in Rakai district of Uganda. Social Science \& Medicine, 50, 203-213. 
Armitage, C. J., \& Conner, M. (2001). Efficacy of the theory of planned behavior: A meta-analytic review. Journal of Applied Social Psychology, 40, 471-499.

Armitage, C. J. (2005). Can the theory of planned behavior predict the maintenance of physical activity? Health Psychology, 24(3), 235-245.

Bandura, A. (1986). Social foundations of thought and action: A social cognitive theory. Eaglewood Cliffs, NJ: Prentice- Hall.

Beiginia, A. R., Besheli, A. S., Soluklu, M. E., \& Ahmadi, M. (2011). Assessing the mobile banking adoption based on the decomposed theory of planned behaviour. European Journal of Economics, Finance \& Administrative Sciences, 28, 7-15.

Bhattacherjee, A. (2000). Acceptance of e-commerce services: The case of electronic brokerages. IEEE Transactions On Systems, Man, And Cybernetics—Part A: Systems \& Humans, 30(4), 411-420.

Chun Hua, S. L., \& Chun, F. C. (2011). Application of theory of planned behaviour on the study of workplace dishonesty. International Conference on Economics, Business and Management IPEDR, IAC IT Press, Manila, Philipine.

Conner, M., \& Armitage, C. J. (1998). Extending the theory of planned behaviour: A review and avenues for further research. Journal of Applied Social Psychology, 28, 1429-1464.

Echchabi, A., \& Aziz, H. A. (2012). Empirical investigation of customers’ perception and adoption towards Islamic banking services in Morocco. Middle-East Journal of Scientific Research, 12(6), 849-858.

Fauziah, M. T., Ramayah, T., \& Dzuljastri, A. R. (2008). Factors influencing intention to use diminishing partnership home financing. International Journal of Islamic \& Middle Eastern Finance and Management, 1(3), 235-248.

Fen, Y. S., \& Sabaruddin, N. A. (2008). An extended model of theory of planned behaviour in predicting exercise intention. International business Research, 1(4), 108-122.

Fishbein, M., \&Ajzen, I. (1975).Belief, attitude, intention, and behavior. Reading, MA: Addison-Wesley.

Fukukawa, K. (2002). Understanding ethically questionable behaviour in consumption: an empirical investigation (Doctoral dissertation). University of Nottingham.

Gibbons, E. X., Gerrard, M., Ouelette, J., \& Burzette, B. (1998). Cogni- tive antecedents to adolescent health risk: Discriminating between behavioral intention and behavioral willingness. Psychology and Health, 13, 319-340.

Hasnah, H., Ishak, I., \& Shaikh, H. A. R. (2011). Factors influencing unethical behavior of insurance agents. International Journal of Business \& Social Science, 2(1), 84-100.

Hendon, R., Zuriah, A. R., \& Sharifah, S. S. H. A. (2009). Economic determinants of family takaful consumption: Evidence from Malaysia. International Review of Business Research Papers, 5(5), 193-211.

Hofstede, G. (1995). Insurance as a product of national values.Geneva papers on risk and insurance, 20(77), 423-429.

Jaruwachirathanakul, B., \& Fink, D. (2005). Internet banking adoption strategies for a developing country: The case of Thailand. Internet Research, 15(3), 295-311.

Lada S., Tanakinjal, G. H., \& Amin, H. (2009). Predicting intention to choose halal products using theory of reasoned action. International Journal of Islamic \& Middle Eastern Finance and Management, 2(1), 66-76.

Leng, G. S., Lada, S., Muhammad, M. Z., Ibrahim, A. A. H. A., \& Amboala, T. (2011). An exploration of social networking sites (SNS) adoption in Malaysia using Technology Acceptance Model (TAM), Theory of Planned Behavior (TPB) and intrinsic motivation. Journal of Internet Banking \& Commerce, 16(2), 1- 27.

Li, S. H., Yu, S. R. L., Hu, H. S., \& Huang, J. S. (2003). Areca quid chewing by Taiwanese adolescents: Application of the Attitudes Social Influence Self-efficacy (ASE) model. Addiction, 98, 1723-1729.

Nurul, H., Nova, R., Yosi, M., \& Purnama, P. (2012). The analysis of attitudes, subjective norms, and behavioral control on muzakki's intention to pay zakah. International Journal of Business \& Social Science, 3(22), 271-279.

Olaniyi, O. N., \& Echchabi, A. (2012). Using theory of reasoned action to model the patronisation behaviour of Islamic banks' customers in Malaysia. Research Journal of Business Management, 6(3), 70-82.

Omar, O. E. (2007). The retailing of life insurance in Nigeria: An assessment of consumers' attitudes. Journal of Retail Marketing Management Research,1(1), 41-47.

Omar, O. E., \& Frimpong, N. O. (2007). Life insurance in Nigeria: An application of the theory of reasoned action to consumers' attitudes and purchase intention. The Service Industries Journal, 27(7), 963-976.

Raedah, S., Noormala, A., \& Marziana, M. (2011). A study on zakah of employment income: Factors that influence academics' intention to pay zakah. Proceedings of the 2nd International Conference on Business and Economic Research (2nd ICBER 2011), 2492-2507.

Ramayah, T., Lee, J. W. C., \& Osman, M. (2010). Green product purchase intention: Some insights from a developing country. Resources, Conservation \& Recycling, 54(12), 1419- 1427. 
Rammal, H. G., \& Zurbruegg, R. (2007). Awareness of Islamic banking products among Muslims: The case of Australia. Journal of Financial Services Marketing, 12(1), 65-74.

Rogers, E. (1983). Diffusion of innovations. New York: Free Press.

Rutherford, L. G., \& DeVaney, S. A. (2009). Utilizing the theory of planned behavior to understand convenience use of credit cards. Journal of Financial Counselling \& Planning, 20(2), 48-63.

Sheppard, B. H., J. Hartwick, \& Warshaw, P. R. (1988). The theory of reasoned action: A meta-analysis of past research with recommendations for modifications and future research. Journal of Consumer Research, 15(3), 325-343.

Siang, L. C., \& Weng, L. K. (2011). Factors affecting non-Muslim consumers towards intention to use Islamic banking products and services. Paper presented at the 2011 Las Vegas International Academic Conference, Las Vegas, Nevada, USA.

Summers, T. A., Belleau, B. D., \& Xu, Y. (2006). Predicting purchase intention of a controversial luxury apparel product. Journal of Fashion Marketing \& Management: An International Journal, 10(4), 405-419.

Syed, S. A., \& Nazura, M. S. (2011). Applying the Theory of Planned Behavior (TPB) in halal food purchasing. International Journal of Commerce \& Management, 21(1), 8-20.

Taylor, S., \& Todd, P. A. (1995). Understanding information technology usage: A test of competing modes. Information System Research, 6(2),144-176.

Thambiah, S., Eze, U. C., Tan, K. S., Nathan, R. J., \& Lai, K. P. (2010). Conceptual framework for the adoption of Islamic retail banking services in Malaysia. Journal of Electronic Banking Systems, 1, 1-10.

Van Der Pligt, J., Zeelenberg, M., van Dijk, W. W., de Vries, N. K., \& Richard, R. (1998). Affect, attitudes and decisions: Let's be more specific. In W. Stroebe \& M. Hewstone (Eds.), European review of social psychology (pp. 33-66). Chichester, UK: Wiley.

Van Es, S. M, Kaptein, A. A., Bezemer, P. D., Nagelkerke, A. F., Colland, V. T., \& Bouter, L. M. (2002). Predicting adherence to prophylactic medication in adolescents with asthma: An application of the ASE-model. Patient Education \& Counseling, 47, 165-171.

Venkatesh, V., Morris, M. G., Davis, G. B., \& Davis, F. D. (2003). User acceptance of information technology: Toward a unified view. MIS Quarterly, 27(3), 425-478.

Vries, D. H., Dijkstra M., \& Kuhlman, P. (1988). Self-efficacy: Third factor besides attitude and subjective norm as a predictor of behavorial intention. Health Education Research, 3(3), 273-82. 